\title{
SPEED CONTROL OF DC MOTOR USING PID CONTROLLER BASED ON MATLAB
}

\author{
M. Ya. Alwardat, P. V. Balabanov
}

Department of Mechatronics and Technological Measurements, moh.alwardat@yahoo.com; Tambov State Technical University,Tambov,Russia

Keywords: DC motor; MATLAB representation; proportional control; integral control; derivative control; error signal; block diagram.

\begin{abstract}
DC motors are widely used in industrial variable speed applications due to their more demanding speed and torque characteristics and easy control aspects. This article introduces a method to control the speed of a DC motor using a PID controller to control the speed of a DC motor, and also uses MATLAB software for calculations and simulation. The choice of PID parameters has been elucidated as a result of several variation experiments.
\end{abstract}

\section{Introduction}

DC motor is a power actuator which transforms electrical energy into mechanical energy. DC motors are most suitable for wide range speed control and are therefore used in many adjustable speed drives. The advantage of dc motors may be speed control. Since speed is directly proportional to armature voltage and inversely proportional to magnetic flux produced by the poles and adjusting the armature voltage and the field current will change the rotor speed. DC motors have been widely used in many industrial applications such as electric cranes, electric vehicles, and robotic manipulators due to wide, simple, and continuous control characteristics [1,2].

DC motors are highly versatile and flexible in aspects of speed control. High performance DC motor drives are popular in industrial applications for its enormous good characteristics such as high starting, accelerating and retard torque, high response performance, rapid braking and easier to be linear control etc. DC motor is a highly controllable electrical actuator and is widely used for robotic manipulators, guided vehicles, steel rolling mills, cutting tool, overhead cranes, electrical traction and other application etc. In comparison to AC drive, DC motor drives are simple and less expensive $[1,3]$.

The design of such a controller requires specification of three parameters: proportional gain, integral time constant and derivative time constant so far, great effort has been devoted to develop methods to reduce the time spent on optimizing the choice of controller parameters [1].

\section{PID controller}

The best-known controllers used in industrial control processes are proportionalintegral-derivative (PID) controllers because of their simple structure and robust performance in a wide range of operating conditions. PID controller is a generic control loop feedback mechanism (controller) widely used in industrial control system [3]. 
The PID controller calculation (algorithm) involves three constant parameters called the proportional (P), integral (I) and derivative (D) values, these values can be interpreted in terms of time. P depends on the present error, I on the accumulation of past error, and D is a prediction of future error, based on current rate of change [4].

These controllers are extremely popular because they can usually provide good closed-loop response characteristics, can be tuned using relatively simple design rules, and are easy to construct using either analog or digital components [5] (Fig. 1).

The PID controller is placed in the forward path, so that its output becomes the voltage applied to the motor's armature. The feedback signal is a velocity, measured by a tachometer. The output velocity signal $y(t)$ is summed with a reference or command signal $R(t)$ to form the error signal $e(t)$. Finally, the error signal is the input to the PID controller (Fig. 2).

At the same time PID controller has some disadvantages, namely, the undesirable speed overshoot and the sluggish response due to sudden change in load torque and the sensitivity to controller gains $K_{I}$ and $K_{P}$. The performance of this controller depends on the accuracy of system models and parameters. There for there is need of a controller which can overcome disadvantages of PID controller. The PID controller output shows the following equation:

$$
U(t)=K_{P} e(t)+K_{I} \int_{0}^{t} e(\tau) d \tau+K_{D} \frac{d e(t)}{d t},
$$

where $K_{P}, K_{I}, K_{D}$ are proportional, integral and derivative constants respectively; $e$ is error signal.

Taking the Laplace transform of this equation gives the transfer function $G(s)$ :

$$
G(s)=\frac{U(t)}{e(t)}=\left(K_{P}+\frac{K_{I}}{s}+K_{D} s\right)
$$

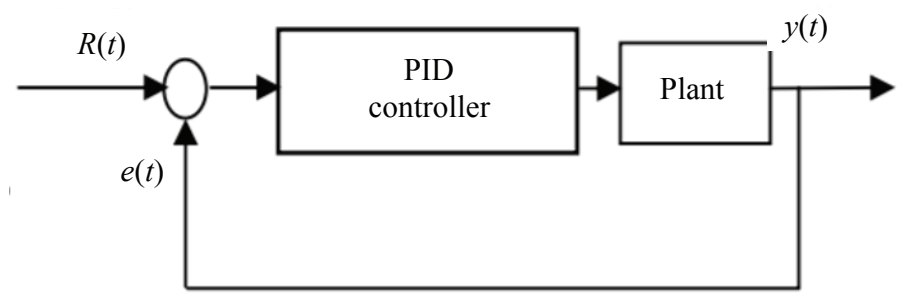

Fig. 1. Feedback system architecture

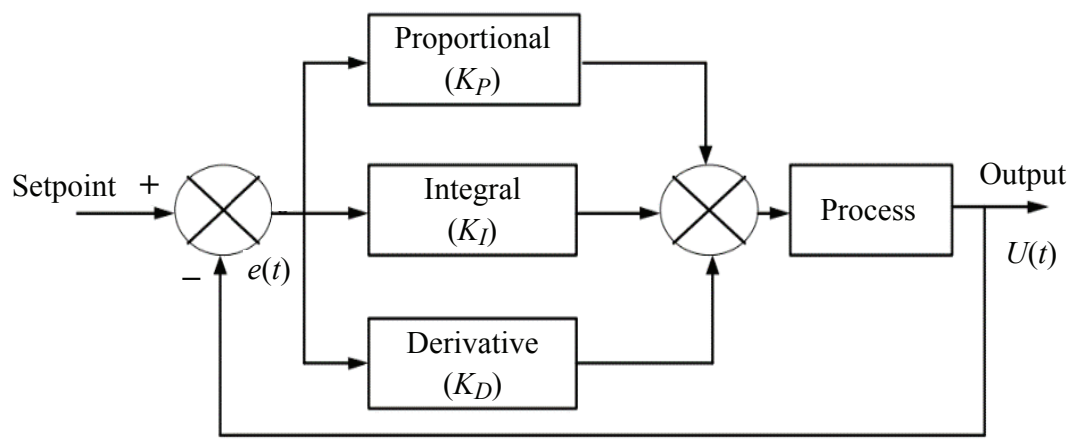

Fig. 2. Block diagram of PID controller 


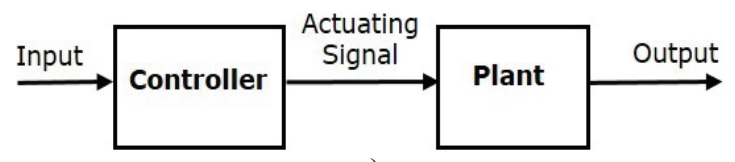

a)

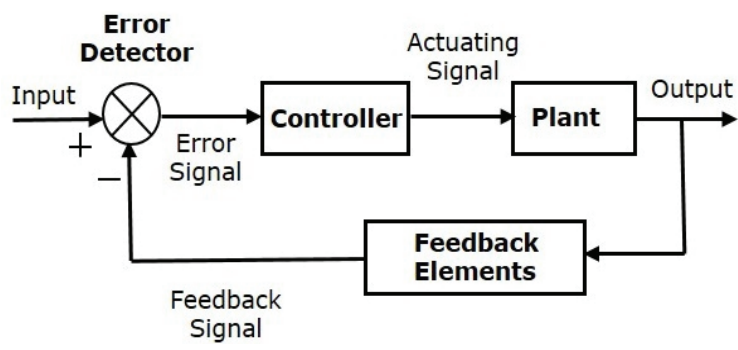

b)

Fig. 3. Block diagram of open (a) and closed (b) loop control system

Before examining the input-output relationships and design methods for the PID controller, it is advisable to review typical characteristics observed for the velocity response of a DC motor to a step voltage input. Different characteristics of the motor response (steady-state error, peak overshoot, rise time, settling time, etc) are controlled by selection of the three gains that modify the PID controller dynamically [6].

In open loop control system, it cannot correct the variation in output automatically. In these systems the output remains constant for a constant input signal. By approximately changing input output may change to desired value and variations in external Conditions may cause the output to change [6,7] (Fig. 3,a).

In closed loop control system, it can correct the variation in output automatically. In these systems the output remains constant for a changing input signal. The measured response of the system is compared with a desired response of the system. The difference between two response gives the actual response of the system [7] (Fig. 3, b).

\section{Motor Model}

This in this section, the entire system is described. This section is divided into two subparts. In the first part, the dynamic model of DC motor speed control is presented (Fig. 4).

The DC motor specifications are as follows:

Shaft power of the motor $=1 \mathrm{kw}$

$\mathrm{Va}$ is armature voltage applied to the motor, $\mathrm{V} ; \mathrm{Va}=110$;

$R a$ is armature-winding resistance, $\mathrm{Om} ; R a=0.378$;

$L a$ is armature-winding inductance, $\mathrm{mH} ; \mathrm{La}=5.9$;

I $a$ is armature-winding current, A;

If is field current, $\mathrm{A}$;

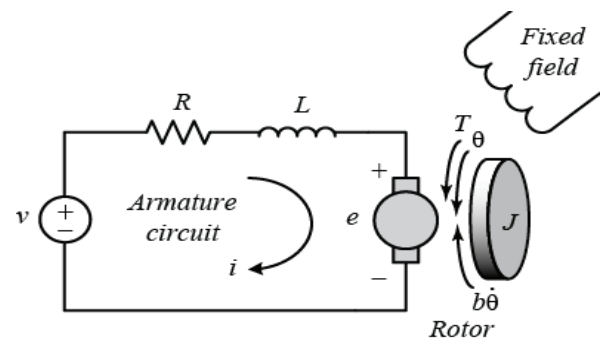

Fig. 4. DC motor model 
$E a$ is applied armature voltage, $\mathrm{V}$;

$E b$ is back emf, V;

$\theta$ is angular displacement of the motor shaft, rad;

$T$ is torque delivered by the motor, $\mathrm{N} \cdot \mathrm{m}$;

$J$ is moment of inertia of the motor and load referred to the motorshaft, $\mathrm{kg} \cdot \mathrm{m}^{2}$; $J=0.018$;

$B$ is equivalent viscous-friction coefficient; $B=0.02$;

In the second part, the proposed controlled system is presented and simulations have been done with MATLAB on Simulink platform.

Modeling DC motor with load (Fig. 5). Output signals Without PID (Fig. 6).

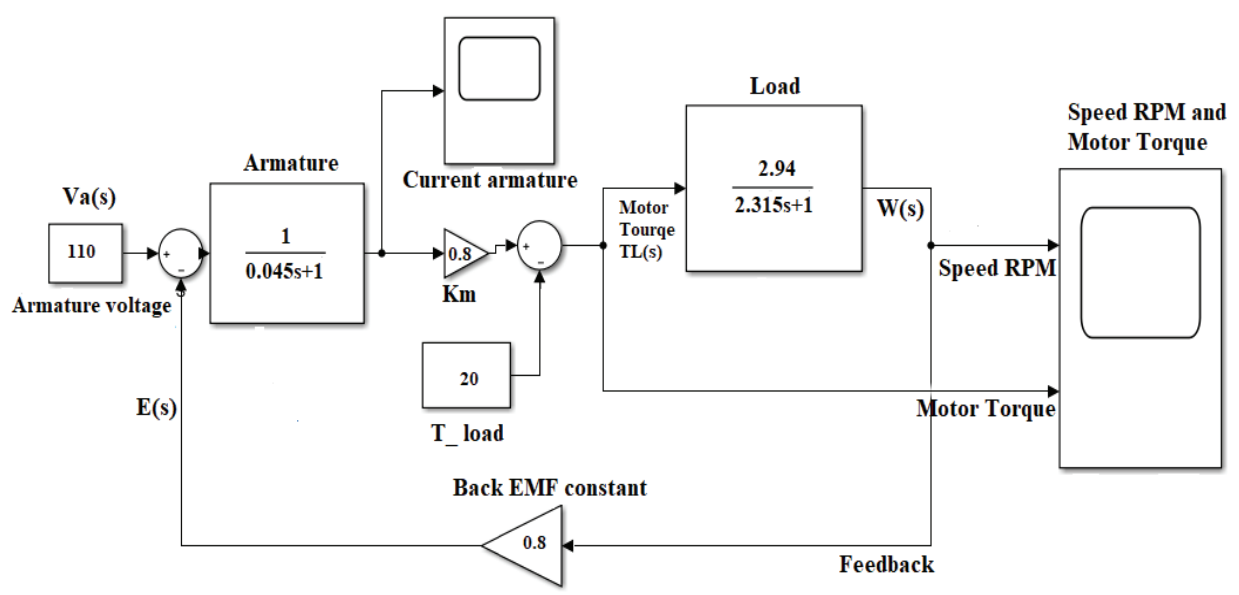

Fig. 5. Simulink model of armature-controlled DC motor with load

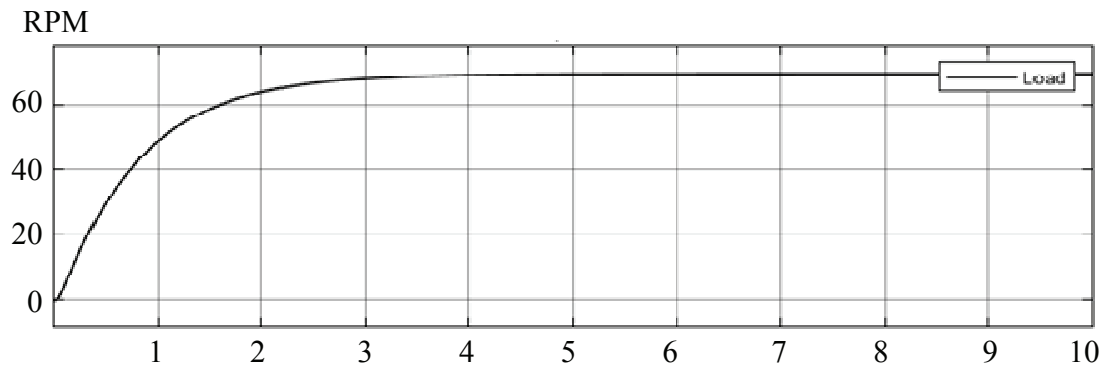

a)

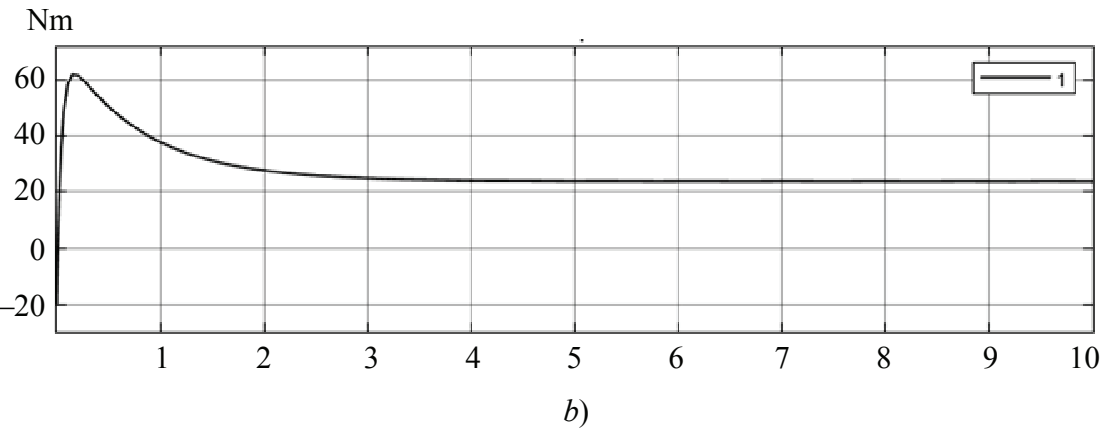

Fig. 6. Uncontrolled DC Motor Speed Response:

$a$-Speed; $b$ - Torque motor 


\section{Motor with PID controller}

The transfer function block diagram of armature controlled separately Excited DC motor with the speed an angular velocity $\omega(\mathrm{s})$ to the applied armature voltage with load. (Fig. 7).

Output signals with PID (Fig. 8).

Characteristics of $\mathrm{P}, \mathrm{I}$, and $\mathrm{D}$ controllers are as follows:

- a proportional controller $K_{P}$ reduces the rise time but it will never eliminate the steady-state error;

- an integral control $K_{I}$ eliminates the steady-state error, but it makes the transient response worse;

- a derivative control $K_{D}$ increases stability of the system, by reducing the overshoot, and it improves the transient response of the system [2] (Table 1, Fig. 9).

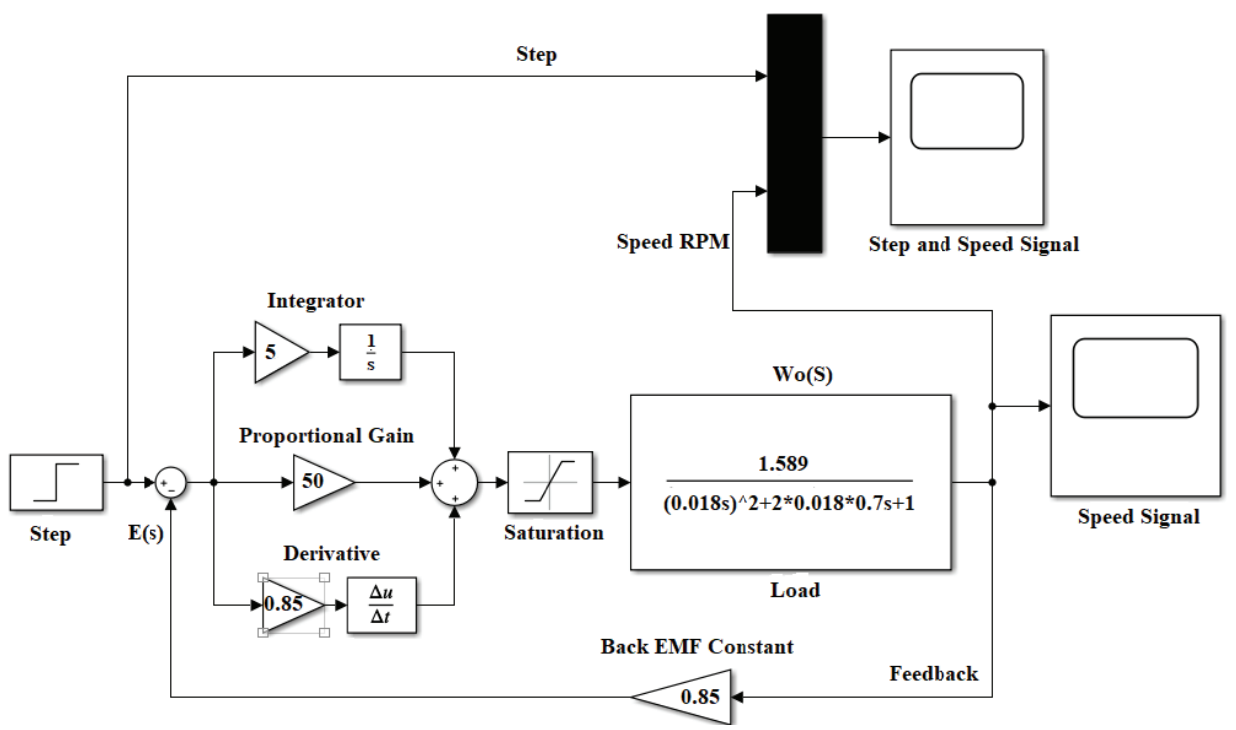

Fig. 7. Block diagram of armature-controlled DC motor with PID controller under the effect of load

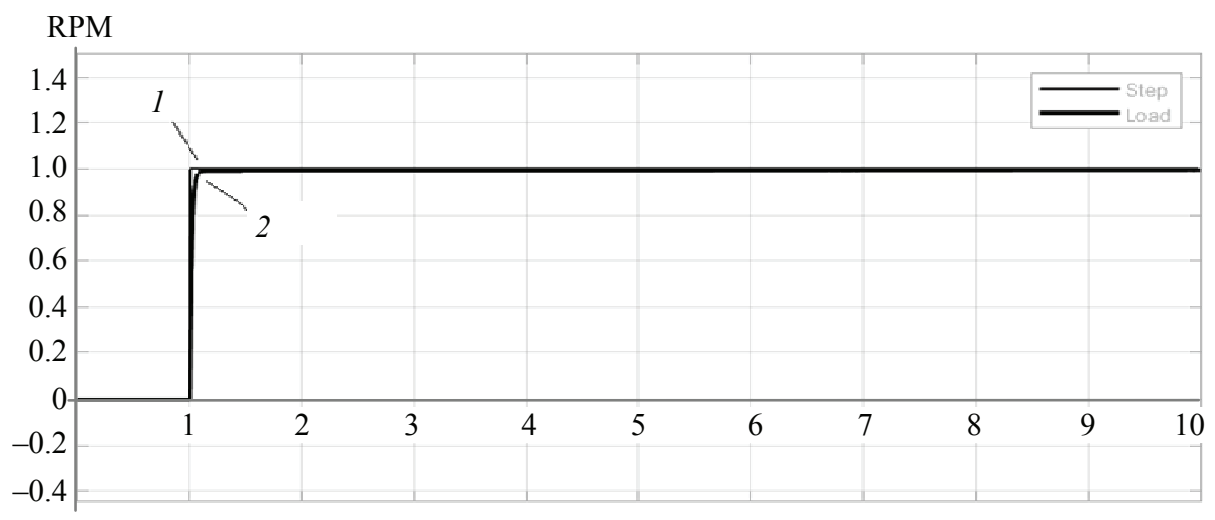

Fig. 8. PID Controlled Response of DC Motor:

1 - Step; 2 - Speed 
Effects of each of controllers $K_{P}, K_{I}$ and $K_{D}$ on a closed-loop system

\begin{tabular}{c|c|c|c|c}
\hline CL Response & Rise time & Overshoot & Settling time & S-S error \\
\hline$K_{P}$ & \multirow{2}{*}{ Decrease } & \multirow{2}{*}{ Increase } & Small change & Decrease \\
\cline { 4 - 5 } \cline { 4 - 5 } & & & Increase & Eliminate \\
\hline$K_{I}$ & Small change & Decrease & Decrease & Small change \\
\hline$K_{D}$ & \multicolumn{2}{|l}{}
\end{tabular}

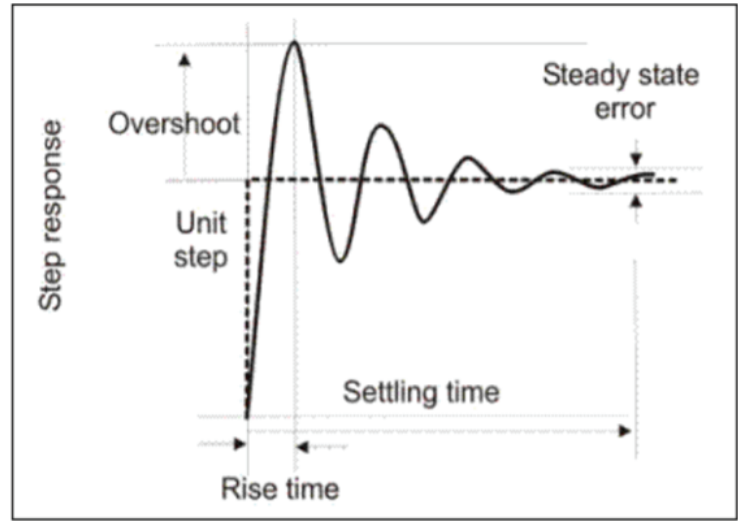

Fig. 9. Properties of response

\section{Conclusion}

This paper presented the separately excited DC motor speed control strategy using PID controller under varying load. The DC motor model was designed with PID controller to control the speed of the motor under the effect of load. The speed of the motor is kept constant and the load torque is varying.

As far as results of the experiment are concerned, it can be concluded that PID controller is very effective and powerful controller that is capable of controlling the open-loop speed control of DC motor under varying load condition. Simulation results of the proposed system proved that PID controller has a better control approach to control and sustain the speed of the motor under varying load condition.

\section{References}

1. O'Dwyer A. PI and PID Controller Tuning Rules: an Overview and Personal Perspective, Proceedings of the IET Irish Signals and Systems Conference, 28 - 30 June, 2006, Dublin, 2006, pp. 161-166.

2. Astrom K.J., Hagglund T. Revisiting the Ziegler-Nichols Step Response Method for PID Control, Journal of Process Control, 2004, vol. 14, no. 6, pp. 635-650.

3. Aras M.S.M., Salim S.N.B.S., Hoo E.C.S., Razak I.A.W.A., Hairi M.H. Comparison Of Fuzzy Control Rules using MATLAB Toolbox and Simulink for DC Induction Motor-Speed Control, International Conference of Soft Computing and Pattern Recognition, 4 - 7 December, 2009, Malacca, Malaysia, 2009, pp. 711-715.

4. Singhal A., Salsbury T.I. A Simple Method for Detecting Valve Stiction in Oscillating Control Loops, Journal of Process Control, 2005, vol. 15, no. 4, pp. 371-382.

5. Djatmiko W., Sutopo B. Speed Control DC Motor under Varying Load Using 
Phase Locked Loop System, International Conference on Electrical, Electronics, Communication and Information CECI, 7-8 March 2001, Jakarta, 2001, vol. 4, no. 2, pp. 150-200.

6. Elsrogy W.M., Fkirin M.A., Hassan M.A.M. Speed Control of DC Motor Using PID Controller Based on Artificial Intelligence Techniques, International Conference on Control, Decision and Information Technologies (CoDIT), 6-8 May, 2013, Hammamet, Tunisia, 2013, pp. 196-201.

7. Perez C., Strefezza M. Speed Control of a DC Motor by Using Fuzzy Variable Structure Controller, 27th Chinese Control Conference, 16 - 18 July, 2008, Kunming, China, 2008, pp. 311-315.

8. Chan H.L., Woo K.T. Closed Loop Speed Control of Miniature Brushless DC Motors, Journal of Automation and Control Engineering, 2015, vol. 3, no. 4, pp. 329-335.

\title{
Управление скоростью двигателя постоянного тока с применением ПИД-регулятора на основе MATLAB
}

\author{
М. Я. Альвардат, П. В. Балабанов \\ Кафедра «Мехатроника и технологические измерения», \\ pav-balabanov@yandex.ru; ФГБОУ ВО «ТГТУ», г. Тамбов, Россия
}

Ключевые слова: блок-схема; двигатель постоянного тока; интегральный контроль; представление MATLAB; производный контроль; пропорциональное управление; сигнал ошибки.

Аннотация: Приведена математическая модель двигателя постоянного тока, широко используемого в промышленных приложениях. Разработана модель замкнутой системы, состоящей из двигателя постоянного тока и ПИД-регулятора скорости вращения его вала, реализованная в Simulink. Осуществлен выбор параметров ПИД - регулятора и построены графики переходного процесса в замкнутой системе, настроенной на технический оптимум.

\section{Список литературы}

1. O'Dwyer, A. PI and PID Controller Tuning Rules: an Overview and Personal Perspective / A. O'Dwyer // Proceedings of the IET Irish Signals and Systems Conference, 28 - 30 June, 2006, Dublin. - Dublin, 2006. - P. 161 - 166.

2. Astrom, K. J. Revisiting the Ziegler-Nichols Step Response Method for PID Control / K. J. Astrom, T. Hagglund // Journal of Process Control. - 2004. - Vol. 14, No. 6. - P. $635-650$.

3. Comparison Of Fuzzy Control Rules using MATLAB Toolbox and Simulink for DC Induction Motor-Speed Control / M. S. M. Aras, S. N. B. S. Salim, E. C. S. Hoo [et al.] // International Conference of Soft Computing and Pattern Recognition, 4 - 7 December, 2009, Malacca, Malaysia. - Malacca, 2009. - P. 711 - 715.

4. Singhal, A. A Simple Method for Detecting Valve Stiction in Oscillating Control Loops / A. Singhal, T. I. Salsbury // Journal of Process Control. - 2005. Vol. 15, No. 4. - P. $371-382$.

5. Djatmiko, W. Speed Control DC Motor under Varying Load Using Phase Locked Loop System / W. Djatmiko, B. Sutopo // International Conference on Electrical, Electronics, Communication and Information CECI, 7-8 March 2001, Jakarta. - Jakarta, 2001. - Vol. 4, No. 2. - P. 150 - 200. 
6. Elsrogy, W. M. Speed Control of DC Motor Using PID Controller Based on Artificial Intelligence Techniques / W. M. Elsrogy, M. A. Fkirin, M. A. M. Hassan // International Conference on Control, Decision and Information Technologies (CoDIT), 6 - 8 May, 2013, Hammamet, Tunisia. - Hammamet, 2013. - P. 196 - 201.

7. Perez, C. Speed Control of a DC Motor by Using Fuzzy Variable Structure Controller / C. Perez, M. Strefezza // 27th Chinese Control Conference, 16 - 18 July, 2008, Kunming, China. - Kunming, 2008. - P. $311-315$.

8. Chan, H. L. Closed Loop Speed Control of Miniature Brushless DC Motors / H. L. Chan, K. T. Woo // Journal of Automation and Control Engineering. - 2015. Vol. 3, No. 4. - P. $329-335$.

\section{Drehzahlregelung des Gleichstrommotors mit Anwendung des PID-Reglers auf MATLAB}

Zusammenfassung: Es ist ein mathematisches Modell des in industriellen Anwendungen weit verbreiteten Gleichstrommotors vorgestellt. Entwickelt ist ein geschlossenes Systemmodell, das aus einem Gleichstrommotor und einem PID-Regler seiner Wellendrehzahl besteht und in Simulink implementiert ist. Die Wahl der Parameter des PID-Reglers ist erfüllt und die auf das technische Optimum abgestimmten Kurven des Einschwingvorgangs im geschlossenen System sind erstellt.

\section{Commande de la vitesse du moteur à courant continu avec l'application du régulateur PID à MATLAB}

Résumé: Est présenté un modèle mathématique du moteur à courant continu largement utilisé dans les applications industrielles. Est élaboré un système en circuit fermé composé d'un moteur à courant continu et d'un régulateur PID de la vitesse de rotation de son arbre, mis en œuvre àSimulink. Est effectuée la sélection des paramètres du régulateur PID est sont construits des graphiques de transition dans un système en boucle fermée réglé en optimum technique.

Авторы: Альвардат Мохаммад Ясин - магистрант; Балабанов Павел Владимирович - доктор технических наук, доцент, исполняющий обязанности заведующего кафедрой «Мехатроника и технологические измерения», ФГБОУ ВО «ТГТУ», г. Тамбов, Россия.

Рецензент: Дмитриевский Борис Сергеевич - доктор технических наук, профессор кафедры «Информационные процессы и управление», ФГБОУ ВО «ТГТУ», г. Тамбов, Россия. 